\title{
Article
}

\section{Comparison of Compaction Alleviation Methods on Soil Health and Greenhouse Gas Emissions}

\author{
Jennifer Bussell ${ }^{1}\left(\mathbb{D}\right.$, Felicity Crotty ${ }^{2}$ and Chris Stoate ${ }^{1, *(1)}$ \\ 1 The Game \& Wildlife Conservation Trust, Allerton Project, Loddington, Leicester LE7 9XE, UK; \\ jbussell@gwct.org.uk \\ 2 Centre for Agriculture, Royal Agricultural University, Cirencester GL7 6JS, UK; felicity.crotty@rau.ac.uk \\ * Correspondence: cstoate@gwct.org.uk; Tel.: +44-1572-717220
}

Citation: Bussell, J.; Crotty, F.; Stoate, C. Comparison of Compaction Alleviation Methods on Soil Health and Greenhouse Gas Emissions. Land 2021, 10, 1397. https://doi.org/ 10.3390/land10121397

Academic Editors: Guido Wyseure, Julián Cuevas González, Jean Poesen and Amrakh I. Mamedov

Received: 22 November 2021 Accepted: 15 December 2021 Published: 17 December 2021

Publisher's Note: MDPI stays neutral with regard to jurisdictional claims in published maps and institutional affiliations.

Copyright: (C) 2021 by the authors. Licensee MDPI, Basel, Switzerland. This article is an open access article distributed under the terms and conditions of the Creative Commons Attribution (CC BY) license (https:// creativecommons.org/licenses/by/ $4.0 /)$.

\begin{abstract}
Soil compaction can occur due to trafficking by heavy equipment and be exacerbated by unfavourable conditions such as wet weather. Compaction can restrict crop growth and increase waterlogging, which can increase the production of the greenhouse gas nitrous oxide. Cultivation can be used to alleviate compaction, but this can have negative impacts on earthworm abundance and increase the production of the greenhouse gas carbon dioxide. In this study, a field was purposefully compacted using trafficking, then in a replicated plot experiment, ploughing, low disturbance subsoiling and the application of a mycorrhizal inoculant were compared as methods of compaction alleviation, over two years of cropping. These methods were compared in terms of bulk density, penetration resistance, crop yield, greenhouse gas emissions and earthworm abundance. Ploughing alleviated topsoil compaction, as measured by bulk density and penetrometer resistance, and increased the crop biomass in one year of the study, although no yield differences were seen. Earthworm abundance was reduced in both years in the cultivated plots, and carbon dioxide flux increased significantly, although this was not significant in summer months. Outside of the summer months, nitrous oxide production increased in the non-cultivated treatments, which was attributed to increased denitrifying activity under compacted conditions.
\end{abstract}

Keywords: nitrous oxide; $\mathrm{N}_{2} \mathrm{O}$; carbon dioxide; $\mathrm{CO}_{2}$; greenhouse gas; compaction; earthworms; direct drilling; bulk density

\section{Introduction}

Soil compaction is a form of soil degradation, which is an issue worldwide, due to the detrimental effects it has on agricultural productivity, through reduced crop growth, increased soil erosion and nutrient depletion [1]. Within England and Wales, almost 4 million hectares of soil are at risk of compaction [2]. Compaction was identified by DEFRA as one of the three key threats to the agricultural and environmental productivity of soils [3] and one of the ten soil threats identified in Europe [4]. Although soil compaction is not a recent phenomenon, some modern farming techniques can exacerbate the risks, including increasing field size and weight of farm equipment $[5,6]$. In this study, we specifically looked at the impact of topsoil compaction exerted by trafficking, which can occur when soils are trafficked by heavy equipment, especially in wet conditions [7,8]. The susceptibility of soils to compaction depends on the interaction between soil physical properties and climate; often soils are workable when soil moisture is lower than field capacity, making the window of opportunity for poorly draining soils particularly narrow [5,9]. Heavy clay soils, such as those found at this experimental site, are therefore often prone to compaction when necessary field operations, such as harvest, coincide with wet weather. This may be exacerbated with the impact of climate change making weather patterns more extreme, with warmer wetter winters and increased occurrences of intense storms, potentially reducing machinery working days [10]. 
Compacted soils have less pore space, and increased bonding between particles, which leads to several problems. They will take more energy to cultivate, and aggregates will be harder to separate [11]. As pore spaces shrink, less space is available for water, and capillary attraction holding water within the soil increases, reducing water availability and plant uptake. Lower pore space and reduced infiltration also reduces soil aeration; this combined with restricted root growth impairs nutrient and water availability, reducing crop growth $[9,12]$. Compacted soils can also have detrimental effects on soil fauna, most notably, earthworms are often cited as being negatively affected by compaction, due to physical crushing and disruption of their burrow network [13]. Earthworms are also considered one of the key biological engineers needed to improve soil structure after compaction [14].

Due to the poor structure of compacted soils, they can become progressively poorer at absorbing rainfall, becoming more anaerobic over time without ameliorative action [14], which can affect microbial activity, subsequent nutrient cycling and greenhouse gas emissions. Carbon dioxide $\left(\mathrm{CO}_{2}\right)$ is produced through many microbial processes [15] and can spike immediately after ploughing due to the flush of $\mathrm{CO}_{2}$ released from the mixing of the microbial community with decomposable substrates and aerated voids produced through tillage [16]. Pore space and pore connectivity allow for oxygen exchange within the soil, and when these are reduced, oxygen will deplete more rapidly leading to anoxic conditions [15] changing microbial activity. The microbial process of denitrification produces nitrous oxide $\left(\mathrm{N}_{2} \mathrm{O}\right)$ and is greatest in wet conditions, so less plant available nitrogen can be found in the soil and more nitrogen is lost to the atmosphere as $\mathrm{N}_{2}$ and $\mathrm{N}_{2} \mathrm{O}$ [17]. As $\mathrm{N}_{2} \mathrm{O}$ has a global warming potential 298 time higher than that of $\mathrm{CO}_{2}$ [18], compaction has implications for global warming emissions as well as soil health and productivity.

The efficacy of three methods for mitigating compaction damage was compared with the direct drilled control to see, not only the impact of these methods on crop production, but also their impact on soil health and greenhouse gas emissions. Ploughing was used as the conventional cultivation method for alleviating topsoil compaction. As ploughing aerates the soil profile, it can accelerate the loss of soil organic carbon (SOC) to the atmosphere as $\mathrm{CO}_{2}$, and destroy soil aggregates, exposing organic carbon for mineralization [19]. The physical process of running a plough through a soil can also have a detrimental effect on earthworm populations $[13,20]$. Both SOC and earthworm numbers have beneficial impacts on aggregate stability and soil structure [21], improving infiltration and resilience to future compaction. Low disturbance subsoiling (LDS) can be used as an alternative method of compaction alleviation, particularly in the subsoil layer, as the topsoil remains undisturbed. LDS theoretically has lower impact on $\mathrm{CO}_{2}$ emissions due to the non-inversion nature of the cultivation, reducing the mixing and oxygenation of SOC, and potentially reducing damage to earthworms in the topsoil layers.

Due to poor root exploration in compacted soils and microbial processes occurring in waterlogged soils, there can be lower access to nutrients for plants $[7,22]$. Mycorrhizal association has been suggested to benefit plants in these conditions, as the excess hyphae network can scavenge nutrients from a larger volume of soil [23,24]. As a final compaction alleviation method, a mycorrhizal inoculant was introduced to help plants overcome the detrimental effects of compaction on nutrient acquisition. The overall aim of the study was to identify the detrimental impacts of topsoil compaction, and to compare methods of alleviating this compaction in terms of their impact on soil compaction, earthworm populations, plant productivity and greenhouse gas emissions.

\section{Materials and Methods}

The experimental area was set up in October 2017 at the Allerton Project-a 300 hectare mixed arable and livestock research, demonstration and education farm (Game \& Wildlife Conservation Trust, Fordingbridge, Hampshire, UK), at Loddington, Leicestershire, UK (N $052^{\circ} 36^{\prime} 53^{\prime \prime} \mathrm{W} 00^{\circ} 50^{\prime} 31^{\prime \prime} ; 186 \mathrm{~m}$ a.s.l). Soils are predominantly a heavy clay loam, UK soil series: Denchworth, texture $47 \%$ clay, $31 \%$ silt, and $22 \%$ sand, soil organic matter $4.2 \%$. To create compaction in the field, a tractor (Massey Ferguson 7720, approximate weight 
8 tonnes) was driven across part of the field $(100 \mathrm{~m} \times 50 \mathrm{~m})$, so that every area of the plots had been passed over by a tractor wheel twice. The compaction was checked using a cone penetrometer (SC 900, Field Scout, Aurora, IL, USA), taking an average of 10 measurements per plot, and showing an average of $15 \%$ higher compaction measured across $45 \mathrm{~cm}$ depth, that peaked at an increase of $32 \%$ at $7.5 \mathrm{~cm}$ depth. Penetration resistance measurements were repeated 4 times across the year.

Plots were arranged across the compacted area in randomized blocks (with tramlines excluded from the experimental treatments), measuring $6 \mathrm{~m}$ wide and $40 \mathrm{~m}$ long, giving an area of $240 \mathrm{~m}^{2}$. The effectiveness of cultivation at alleviating the compaction was tested using four treatments: plough, low disturbance subsoiler (LDS), mycorrhizal inoculant (AMF), and a no cultivation direct drilled control. Cultivations took place each year in autumn. Plough plots were ploughed to a depth of $25 \mathrm{~cm}$, then disked to a depth of $10 \mathrm{~cm}$ (Väderstad carrier); LDS plots were subsoiled to a depth of $30 \mathrm{~cm}$; AMF plots received a granular application of inoculant SR1:Cereals (Plantworks Ltd., Sittingbourne, UK) drilled with the crop at a rate of $10 \mathrm{~kg} / \mathrm{ha}$; while direct drill plots only received a straw rake before drilling. All crops were established using a direct drill (Eco M, Dale Drills, Market Rasen, UK) and standard farm practice was used for the application of manufactured fertiliser and plant protection products, which was consistent across all plots. Following cultivations in October 2017, Hordeum vulgare was planted across all plots and harvested in July 2018. The compaction and cultivation treatments were repeated in October 2018 keeping the same plot structure and Vicia faba was planted across all plots and harvested in September 2019.

Topsoil bulk density 0-10 cm was measured yearly in spring using a bulk density ring (10 cm depth, $5 \mathrm{~cm}$ diameter); three measurements were averaged per plot. Yield was taken from the combine as each plot was harvested. Plant biomass was also taken before combine harvest, by cutting three $0.25 \mathrm{~m}^{2}$ quadrats per plot, and drying the biomass in an oven at $70{ }^{\circ} \mathrm{C}$ until a stable weight was achieved. Earthworm abundance was measured using three replicates of $20 \times 20 \times 25 \mathrm{~cm}$ soil blocks per plot that were removed by spade. Soil was sorted by hand and all worms were counted and weighed.

Greenhouse gas measurements were taken monthly across the two cropping seasons using an FT-IR gas analyser (DX4040, Gasmet, Helsinki, Finland), set to measure $\mathrm{CO}_{2}$ and $\mathrm{N}_{2} \mathrm{O}$ simultaneously, with a $20 \mathrm{~cm}$ soil survey chamber attached (Li-cor). Plastic rings (20 cm diameter) were placed in the soil to a depth of $10 \mathrm{~cm}$, allowing a $15 \mathrm{~cm}$ lip above the soil, at least $48 \mathrm{~h}$ before the first measurement. The chamber formed an airtight seal when placed on top of the rings. Gas flux was measured over 10 min, with the machine set to average measurements over $60 \mathrm{~s}$. The initial $4 \mathrm{~min}$ were discarded to allow for gas equilibration in the system, and gas flux was calculated from the increase in gas concentration measured over the remaining 6 min. $\mathrm{N}_{2} \mathrm{O}$ was multiplied by 298 to give an equivalent global warming potential to $\mathrm{CO}_{2}$ to make comparisons between these two greenhouse gasses [18].

Statistical analysis used the Genstat software package [25]. A one-way ANOVA was used for all statistics, with the exception of the penetration resistance analysis. Where multiple measurements were taken, a repeated measures ANOVA was used. For penetration resistance, a principal component analysis (PCA) reduced the dimensionality of data, so comparisons between treatments at all depths could be made. PC1 (containing 75.53\% of the overall variation) was used in a repeated measures ANOVA to test between treatments over the multiple measurement times.

\section{Results}

Penetration resistance showed significantly higher compaction in the uncultivated (AMF and control) plots $(p=0.002)$, which was mostly due to differences within the $7.5-25 \mathrm{~cm}$ depth range (Figure 1). There was also a significant impact of measurement time $(p=0.008)$ due to variation in soil condition over the year. 


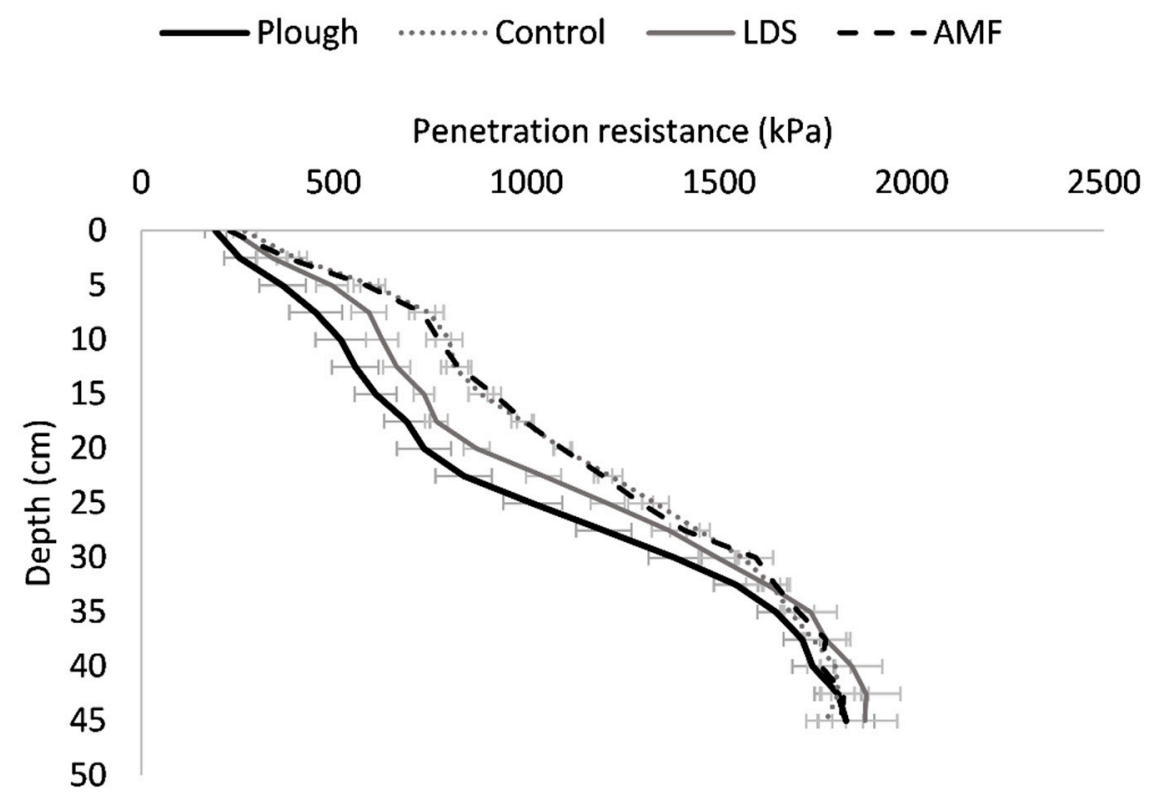

Figure 1. Penetration resistance $(\mathrm{kPa})$ measured $0-45 \mathrm{~cm}$ depth through the soil profile. Graph shows average \pm SE of all readings taken across the two years of measurements.

Bulk density $(0-10 \mathrm{~cm})$ measurements only showed significant results in the first year. Bulk density was lower in the ploughed plots, but surprisingly, significantly higher in the LDS plots $(p<0.001)$ (Figure 2). Bulk density measurements taken in the second year followed the same trend, with plough the lowest and LDS treatment as the highest, but this was not significant.

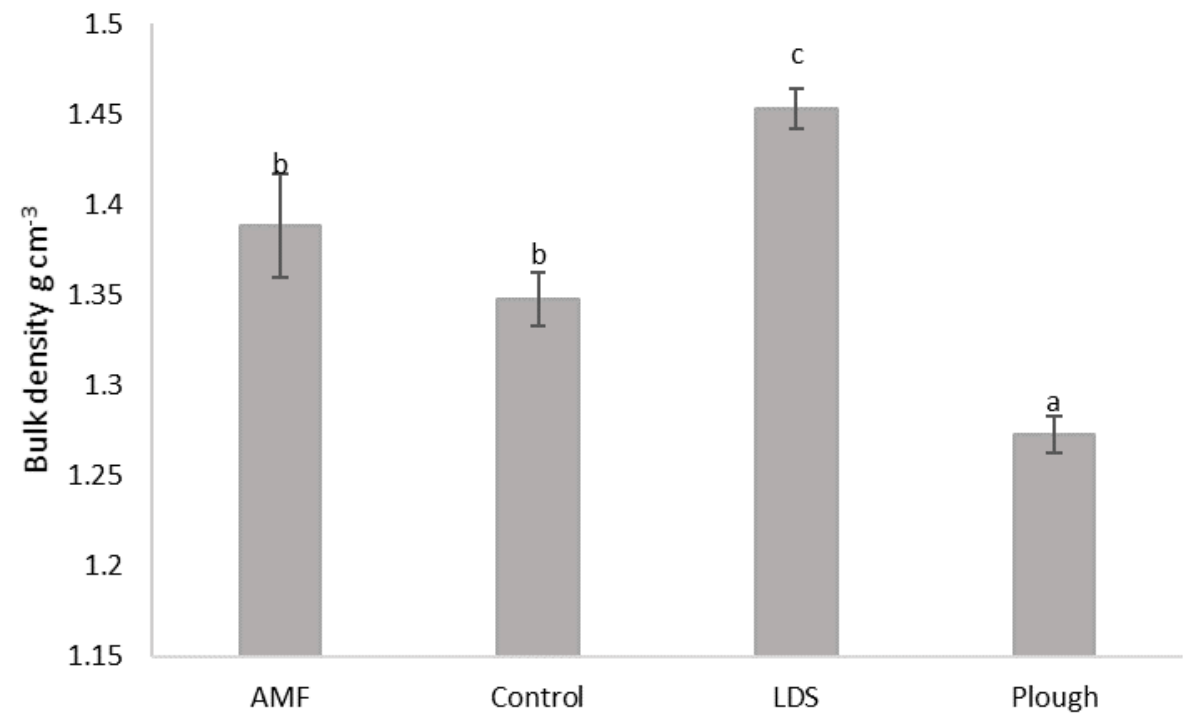

Figure 2. Soil bulk density $\left(\mathrm{g} \mathrm{cm}^{-3}\right)$ measured in the topsoil 0-10 $\mathrm{cm}$ in 2018. Bars show mean $\pm \mathrm{SE}$. Letters denote significant differences at $p<0.05$.

Despite the measurable compaction, it was not strong enough to influence yield, with no difference seen in crop yield seen in the two years. For the 2018 barley (Hordeum vulgare) crop, overall plant biomass was significantly $(p<0.001)$ higher in the two cultivated plots (Figure 3), but no biomass differences were seen in the subsequent bean crop (Vicia faba). 


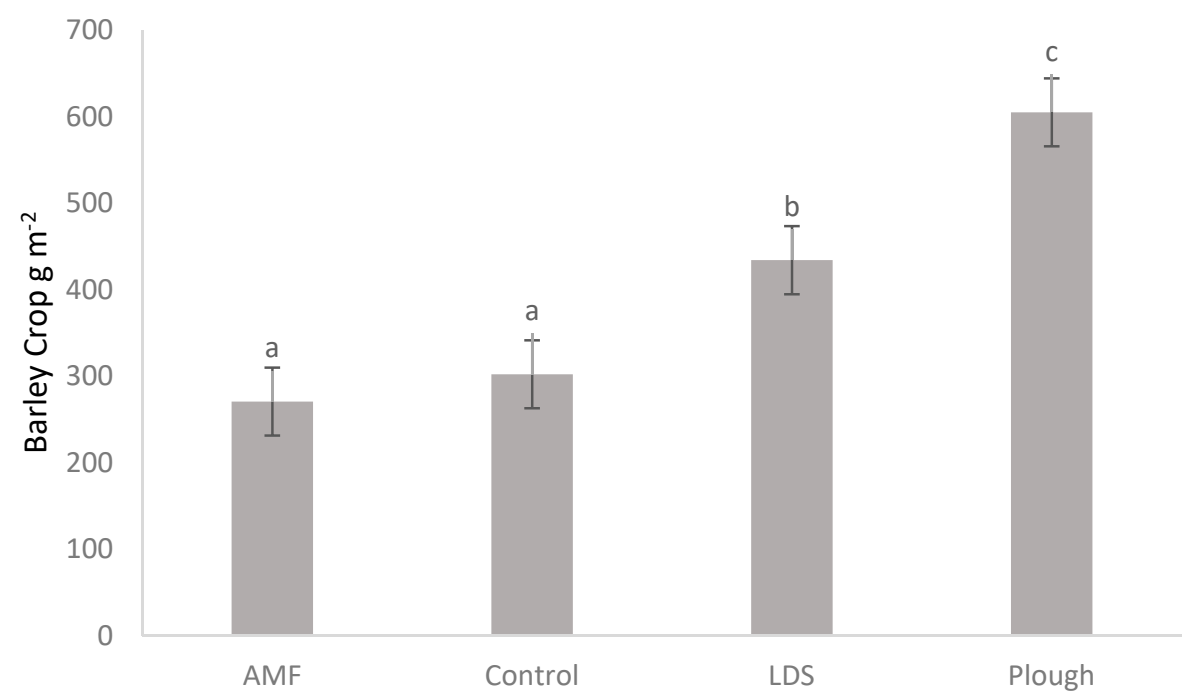

Figure 3. Barley crop (Hordeum vulgare) plant biomass measured in May 2018. Bars show mean \pm SE. Letters denote significant differences at $p<0.05$.

Earthworm numbers were higher in the non-cultivated plots (AMF and control) in both years $(p=0.046)$ (Figure 4$)$. There was a highly significant difference between years $(p>0.001)$, with 2019 having less than half the number of worms counted in 2018 (average $411 \pm 65$ in 2018, $172 \pm 28$ in 2019).

\section{Earthworm abundance}

$2018 \square 2019$

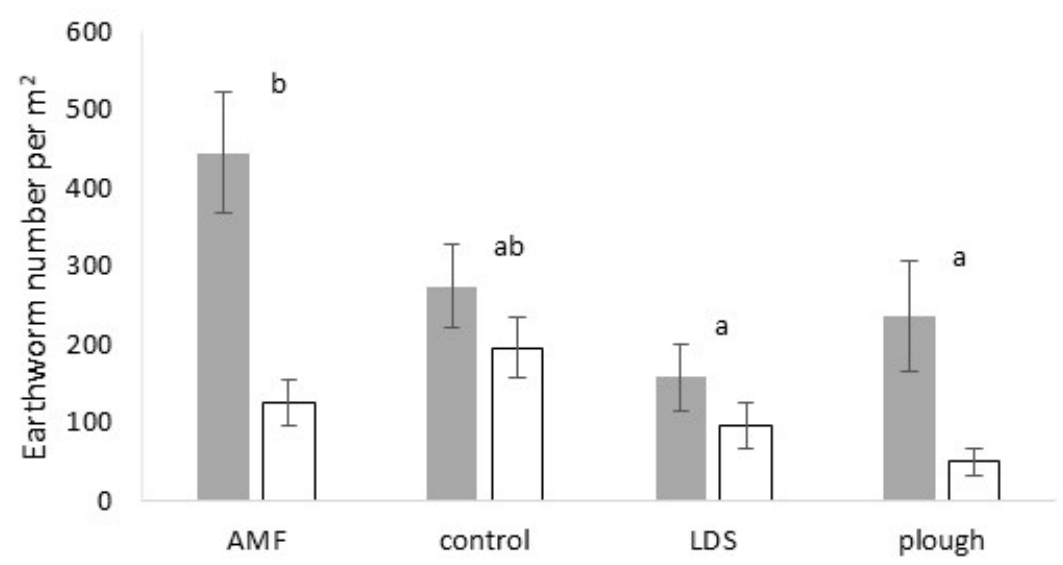

Figure 4. Average earthworm number (per $\mathrm{m}^{2}$ ) measured in 2018 and 2019, to a depth of $25 \mathrm{~cm}$. Bars show mean \pm SE. Letters denote significant differences between cultivation treatments for both years at $p<0.05$.

$\mathrm{N}_{2} \mathrm{O}$ and $\mathrm{CO}_{2}$ were measured monthly during cropping. Initially, repeated measures ANOVA showed no significant treatment effects for $\mathrm{CO}_{2}(p=0.076)$, however, splitting the results by season resulted in significant treatment effects for $\mathrm{CO}_{2}$ flux in the winter months $(p=0.034)$, with ploughed plots having significantly higher $\mathrm{CO}_{2}$ emissions (Figure 5). Initial $\mathrm{N}_{2} \mathrm{O}$ emissions analysis showed significant treatment differences $(p=0.046)$, with significant differences between sampling times $(p<0.001)$ and a significant interaction between treatment and time $(p=0.033)$. Further investigation showed the interaction was due to much lower $\mathrm{N}_{2} \mathrm{O}$ emissions during the warmer drier summer months. Breaking the analysis down into summer months (June, July and August) and all the other months (referred to as winter for simplicity), gave significant treatment effects for winter months $(p=0.037)$, with the AMF and the control plots showing much higher $\mathrm{N}_{2} \mathrm{O}$ emissions 
(Figure 6), but no significant effects were seen in summer months due to the overall lower emissions. The $\mathrm{CO}_{2}$ and $\mathrm{N}_{2} \mathrm{O}$ results were combined to give total green-house gas emissions for winter. The combined gasses showed no significant treatment differences in total gas fluxes recorded in winter $(p=0.595)$, although the composition of the gas fluxes changes between the plots.

winter $\square$ Summer

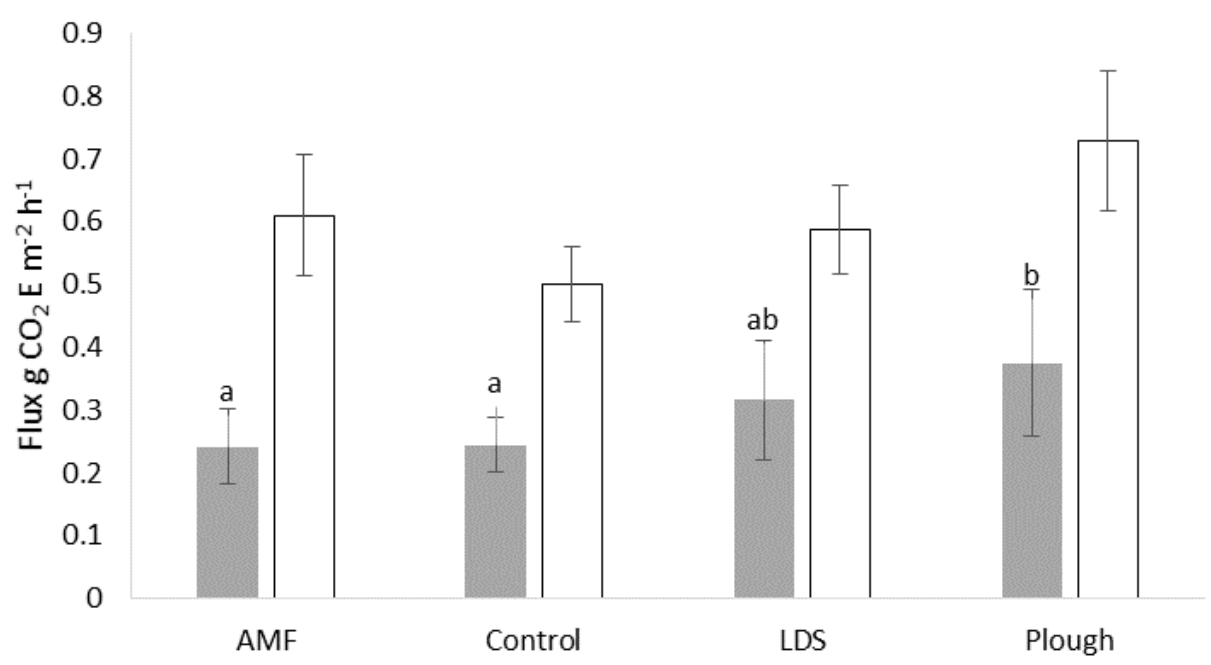

Figure 5. $\mathrm{CO}_{2}$ flux measured monthly during 2018-2019 cropping and averaged over summer (June, July, August) and winter (all other months). Bars show mean $\pm \mathrm{SE}$. Letters denote significant differences between winter treatments at $p<0.05$.

Winter $\square$ Summer

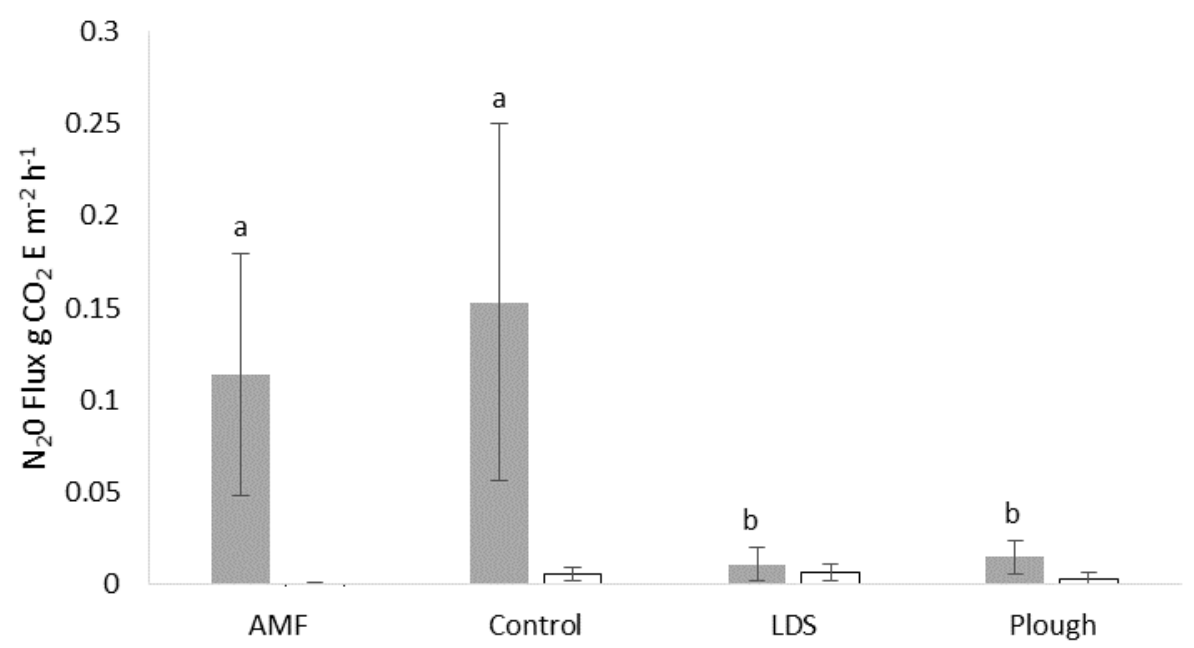

Figure 6. $\mathrm{N}_{2} \mathrm{O}$ flux measured monthly during 2018-2019 cropping and averaged over summer (June, July, August) and winter (all other months). $\mathrm{N}_{2} \mathrm{O}$ flux is displayed as $\mathrm{CO}_{2}$ equivalent by 298. Bars show mean \pm SE. Letters denote significant differences at $p<0.05$.

\section{Discussion}

Direct drilling is established as a management practice that can improve aspects of soil health by leaving the soil undisturbed, which helps build soil organic matter and soil biology, such as earthworm populations. However, it does require soil to be in a fit state for conversion to direct drilling; compaction is a common problem across agricultural land, and can lead to issues including reduced root growth, reduced water and nutrient uptake and overall reduced productivity if not resolved with some form of compaction alleviation. This study compared the effectiveness of ploughing, low disturbance subsoiling 
and mycorrhizal inoculation as compaction alleviation methods to direct drilling over a compacted area.

Uncultivated plots, AMF and the control plots had significantly higher compaction in the $7.5-20 \mathrm{~cm}$ range (Figure 1), when measured using a penetrometer. This is unsurprising, as this is the depth of soil that would have been influenced by the plough and the LDS cultivations. High penetration resistance scores of 1000-2000 kPa are linked with slower root elongation rates [26] and thicker roots, due to the increased pressure needed to penetrate the soil [27], which can be detrimental to plant growth as they require extra energy to explore the soil. A lower proliferation of roots can also result in reduced nutrient and water access for the crop. However, in this experiment compaction only reached above $1000 \mathrm{kPa}$ at a depth of approximately $20 \mathrm{~cm}$ (Figure 1), suggesting that compaction in the topsoil where cultivation was used was not large enough to elicit a yield response. In 2018, a plant biomass response was seen in the barley crop, with smaller plants in the uncultivated plots (Figure 3). Previous studies have suggested that monocot crops are more capable of tolerating compaction than dicot crops [28], which could explain the difference between the response in the barley and the bean crop. Bulk density measurements taken in the top $10 \mathrm{~cm}$ of soil showed that ploughing resulted in the least densely packed topsoil, while LDS, surprisingly, resulted in the highest compacted topsoil (Figure 2). Subsoilers are designed to alleviate compaction at lower levels, leaving the topsoil relatively undisturbed. However, in some cases, subsoilers have been recorded to increase the compaction at the soil surface [29].

Earthworm numbers have been linked to improved infiltration [30], plant rooting depth [31], aggregate stability [21] and overall plant production [32], making them an excellent indicator of soil biological health [33]. Previous studies have suggested that earthworm populations diminish under cropping compared to pastureland, and under tillage compared to untilled cropped systems [34], which has been attributed to the mechanical damage and destruction of the earthworm habitat [20]. However, there is evidence that soil conditions such as high bulk density and low soil pore space caused by compaction can have adverse effects on earthworm populations, sometimes reducing numbers in uncultivated systems [35]. In the present study, earthworm numbers were significantly reduced under the cultivated treatments LDS and plough, across both years measured (Figure 4), suggesting mechanical damage had reduced the earthworm population, with potential detrimental effect on soil health and plant productivity in these plots. This highlights the trade-off between cultivation to alleviate the damaging effects of compaction, with the disturbance this causes on soil fauna needed for healthy soil processes. A long period of drought in 2018 is likely to have been a factor in the reduction in earthworm abundance between years. As the climate changes and the likelihood of prolonged droughts increases, these deleterious effects on earthworm populations will continue [36].

Direct drilling can reduce $\mathrm{CO}_{2}$ emissions and lead to an overall accumulation of SOC, due to an increase in aggregate stability and a change in chemical composition of carbon to more recalcitrant forms [37]. $\mathrm{N}_{2} \mathrm{O}$ is also a greenhouse gas emitted from soils, but with a far higher global warming potential than $\mathrm{CO}_{2}$ [18]. The production of $\mathrm{N}_{2} \mathrm{O}$ is primarily through denitrification, which increases when water-filled pore spaces within soils are around 65-75\% [38]. As direct drilled soils generally have a greater bulk density, particularly if newly converted or previously compacted as in the present experiment, water-filled pore space is often higher favouring denitrification [39]. Bulk density measurements taken in this experiment were significantly lower in ploughed plots, suggesting that water-filled pore spaces would be similarly lower under the ploughed treatment (Figure 3). Higher bulk density was seen in the LDS plots, but this was only measured in the top $10 \mathrm{~cm}$, as the LDS is designed not to disturb the topsoil, but to alleviate compaction at lower depths; there may still have been higher pore space lower down in the soil profile, which the penetration resistance measurement confirms (Figure 1).

Greenhouse gas flux measurements showed overall higher $\mathrm{CO}_{2}$ emissions in the summer months (June, July and August), when soil activity is at its highest due to warmer 
temperatures. No significant treatment differences were seen in $\mathrm{CO}_{2}$ emissions between treatments in these warmer months, but when all other months were analysed together, significantly higher $\mathrm{CO}_{2}$ emissions were seen from the two cultivated treatments, LDS and plough (Figure 5), due to the mechanical stimulation of organic matter breakdown in the soil [16]. In contrast, $\mathrm{N}_{2} \mathrm{O}$ was produced at a much higher rate during the winter months than the summer months. During the winter months, there was significantly higher production of $\mathrm{N}_{2} \mathrm{O}$ under the two non-cultivated treatments, AMF and control (Figure 6). These results are similar to those seen by Gregorich et al. [40], who found an increase in $\mathrm{N}_{2} \mathrm{O}$ production in compacted soils, which corresponded to precipitation and high soil water content and was not seen in uncompacted treatments under the same conditions. Similarly, additional experiments at the site of our experiment, which used direct drill treatments without prior compaction have not shown this increase in $\mathrm{N}_{2} \mathrm{O}$ flux (data not shown). Therefore, the increase in $\mathrm{N}_{2} \mathrm{O}$ flux seen within this experiment was attributed to the reduced pore space, and subsequent increased water-filled pores in the compacted soil during the wetter winter months, causing an increase in denitrification activity and $\mathrm{N}_{2} \mathrm{O}$ emissions. This has implications for compacted soils exacerbating $\mathrm{N}_{2} \mathrm{O}$ emissions under future climate predictions of warmer wetter winters [10].

\section{Conclusions}

Overall, the efficacy of three methods of mitigating compaction damage to soil health and greenhouse gas emissions were compared with a direct drilled control. Two methods tried to improve soil structure and reduce compaction mechanically in situ, whilst the third, a biological method, attempted to reduce the impact of compaction on plant growth and nutrient acquisition. This study highlighted that compaction alleviation techniques differ in their efficacy as well as differing in their impact on soil health and greenhouse gas emissions. Earthworm abundance, a key indicator of soil health, was significantly reduced in the mechanical alleviation treatments, whilst emissions of $\mathrm{CO}_{2}$ also increased. However, the link between compaction and increased $\mathrm{N}_{2} \mathrm{O}$ emissions during wetter months is concerning, as seen in the AMF treatment and the direct drill control. Considering around $30 \%$ of soils in Europe are at risk (or susceptible) to compaction [4] and that winter rainfall is expected to increase due to climate change [18], greenhouse gas emissions may increase, dependent on agricultural (mis)management. This study highlights the importance of understanding how to alleviate compaction if we want to reach our climate emission goals and become net-zero within agriculture by 2040 .

Author Contributions: Conceptualization, C.S. and F.C.; methodology, F.C. and J.B.; formal analysis, J.B.; data curation, J.B.; writing—original draft preparation, J.B.; writing—review and editing, C.S. and F.C. All authors have read and agreed to the published version of the manuscript.

Funding: This project has received funding from the European Union HORIZON2020 Programme for research, technological development and demonstration under grant agreement no. 677407.

Institutional Review Board Statement: Not applicable.

Informed Consent Statement: Not applicable.

Data Availability Statement: The data that support the findings of this study are available from the corresponding author upon reasonable request and approval from the study site representatives.

Acknowledgments: Thanks to Plantworks Ltd., Kent, UK, for providing the SR1 Cereals inoculant. Thanks to Gemma Fox for technical support in taking measurements and Phil Jarvis and Oliver Carrick for technical support in creating and maintaining plots.

Conflicts of Interest: The authors declare no conflict of interest. The funders had no role in the design of the study; in the collection, analyses, or interpretation of data; in the writing of the manuscript, or in the decision to publish the results. 


\section{References}

1. Shah, A.N.; Tanveer, M.; Shahzad, B.; Yang, G.; Fahad, S.; Ali, S.; Bukhari, M.A.; Tung, S.A.; Hafeez, A.; Souliyanonh, B. Soil compaction effects on soil health and crop productivity: An overview. Environ. Sci. Pollut. Res. 2017, 24, 10056-10067. [CrossRef]

2. Environment Agency; Chief Scientist's Group. The State of the Environment: Soil; Environment Agency: London, UK, 2019.

3. DEFRA. Environmental Standards for Farming-Consultation on Proposed Changes to Standards in Cross Compliance Good Agricultural and Environmental Condition (GAEC) and Related Measures in England; Department for Environment Food \& Rural Affairs: London, UK, 2009.

4. Jones, A.; Panagos, P.; Barcelo, S.; Bouraoui, F.; Bosco, C.; Dewitte, O.; Gardi, C.; Hervás, J.; Hiederer, R.; Jeffery, S.; et al. The State of Soil in Europe: A contribution of the JRC to the European Environment Agency's Environment State and Outlook Report-SOER 2010; Publications Office of the European Union: Luxembourg, 2012.

5. Batey, T. Soil compaction and soil management-A review. Soil Use Manag. 2009, 25, 335-345. [CrossRef]

6. Akker, J.V.D.; Arvidsson, J.; Horn, R. Introduction to the special issue on experiences with the impact and prevention of subsoil compaction in the European Union. Soil Tillage Res. 2003, 73, 1-8. [CrossRef]

7. Gregory, A.S.; Ritz, K.; McGrath, S.; Quinton, J.; Goulding, K.; Jones, R.J.A.; Harris, J.; Bol, R.; Wallace, P.; Pilgrim, E.S.; et al. A review of the impacts of degradation threats on soil properties in the UK. Soil Use Manag. 2015, 31, 1-15. [CrossRef]

8. Obour, P.B.; Ugarte, C.M. A meta-analysis of the impact of traffic-induced compaction on soil physical properties and grain yield. Soil Tillage Res. 2021, 211, 105019. [CrossRef]

9. Chamen, W.T.; Moxey, A.P.; Towers, W.; Balana, B.; Hallett, P. Mitigating arable soil compaction: A review and analysis of available cost and benefit data. Soil Tillage Res. 2015, 146, 10-25. [CrossRef]

10. Lowe, J.A.; Howard, T.P.; Pardaens, A.; Tinker, J.; Holt, J.; Wakelin, S.; Milne, G.; Leake, J.; Wolf, J.; Horsburgh, K.; et al. UK Climate Projections Science Report: Marine and Coastal Projections; Met Office Hadley Centre: Exeter, UK, 2009.

11. Chamen, W.; Cavalli, R. The effect of soil compaction on mole plough draught. Soil Tillage Res. 1994, 32, 303-311. [CrossRef]

12. Arvidsson, J.; Håkansson, I. Do effects of soil compaction persist after ploughing? Results from 21 long-term field experiments in Sweden. Soil Tillage Res. 1996, 39, 175-197. [CrossRef]

13. Crotty, F.V. Soil Organisms Within Arable Habitats. In The Changing Status of Arable Habitats in Europe; Hurford, C., Wilson, P., Storkey, J., Eds.; Springer: Cambridge, UK, 2020; pp. 123-138.

14. Whalley, R.; Dumitru, E.; Dexter, A. Biological effects of soil compaction. Soil Tillage Res. 1995, 35, 53-68. [CrossRef]

15. Ball, B.C. Soil structure and greenhouse gas emissions: A synthesis of 20 years of experimentation. Eur. J. Soil Sci. 2013, 64, 357-373. [CrossRef]

16. Reicosky, D.; Dugas, W.; Torbert, H. Tillage-induced soil carbon dioxide loss from different cropping systems. Soil Tillage Res. 1997, 41, 105-118. [CrossRef]

17. Højberg, O.; Revsbech, N.P.; Tiedje, J.M. Denitrification in Soil Aggregates Analyzed with Microsensors for Nitrous Oxide and Oxygen. Soil Sci. Soc. Am. J. 1994, 58, 1691-1698. [CrossRef]

18. IPCC. Climate Change 2013: The Physical Science Basis. Contribution of Working Group I to the Fifth Assessment Report of the Intergovernmental Panel on Climate Change; Cambridge University Press: Cambridge, UK; New York, NY, USA, 2013.

19. Liu, X.; Herbert, S.; Hashemi, A.; Zhang, X.; Ding, G. Effects of agricultural management on soil organic matter and carbon transformation-A review. Plant Soil Environ. 2011, 52, 531-543. [CrossRef]

20. Briones, M.J.; Schmidt, O. Conventional tillage decreases the abundance and biomass of earthworms and alters their community structure in a global meta-analysis. Glob. Chang. Biol. 2017, 23, 4396-4419. [CrossRef]

21. Six, J.; Bossuyt, H.; Degryze, S.; Denef, K. A history of research on the link between (micro) aggregates, soil biota, and soil organic matter dynamics. Soil Tillage Res. 2004, 79, 7-31. [CrossRef]

22. Colombi, T.; Keller, T. Developing strategies to recover crop productivity after soil compaction-A plant eco-physiological perspective. Soil Tillage Res. 2019, 191, 156-161. [CrossRef]

23. Elzenga, J.T.M.; van Veen, H. Waterlogging and plant nutrient uptake. In Waterlogging Signaling and Tolerance in Plants; Springer: Berlin/Heidelberg, Germany, 2010; pp. 23-35.

24. Wu, Q.-S.; Zou, Y.-N.; Huang, Y.-M. The arbuscular mycorrhizal fungus Diversispora spurca ameliorates effects of waterlogging on growth, root system architecture and antioxidant enzyme activities of citrus seedlings. Fungal Ecol. 2013, 6, 37-43. [CrossRef]

25. VSN International. Genstat for Windows 18th Edition; VSN International: Hemel Hempstead, UK, 2015; Available online: Genstat.co.uk (accessed on 29 January 2020).

26. Bennie, A.T.P.; Burger, R.D.T. Root characteristics of different crops as affected by mechanical resistance in fine sandy soils. In Tenth National Congress of the Soil Science Society of Southern Africa; SSSA: Lusakav, Zambia, 1983; pp. 29-32.

27. Nosalewicz, A.; Lipiec, J. The effect of compacted soil layers on vertical root distribution and water uptake by wheat. Plant Soil 2013, 375, 229-240. [CrossRef]

28. Sadras, V.O.; O'Leary, G.J.; Roget, D.K. Crop responses to compacted soil: Capture and efficiency in the use of water and radiation. Field Crop. Res. 2005, 91, 131-148. [CrossRef]

29. Bernier, H.; Bostock, G.; Raghavan, G.S.V.; Broughton, R.S. Subsoiling Effects on Moisture Content and Bulk Density in the Soil Profile. Appl. Eng. Agric. 1989, 5, 24-28. [CrossRef]

30. Andriuzzi, W.S.; Pulleman, M.M.; Schmidt, O.; Faber, J.H.; Brussaard, L. Anecic earthworms (Lumbricus terrestris) alleviate negative effects of extreme rainfall events on soil and plants in field mesocosms. Plant Soil 2015, 397, 103-113. [CrossRef] 
31. Kemper, W.D.; Schneider, N.N.; Sinclair, T.R. No-till can increase earthworm populations and rooting depths. J. Soil Water Conserv. 2010, 66, 13A-17A. [CrossRef]

32. van Groenigen, J.W.; Lubbers, I.M.; Vos, H.M.; Brown, G.G.; De Deyn, G.B.; van Groenigen, K.J. Earthworms increase plant production: A meta-analysis. Sci. Rep. 2014, 4, 6365. [CrossRef] [PubMed]

33. Stroud, J.L. Soil health pilot study in England: Outcomes from an on-farm earthworm survey. PLoS ONE 2019, 14, e0203909. [CrossRef] [PubMed]

34. Chan, K. An overview of some tillage impacts on earthworm population abundance and diversity-Implications for functioning in soils. Soil Tillage Res. 2001, 57, 179-191. [CrossRef]

35. Söchtig, W.; Larink, O. Effect of soil compaction on activity and biomass of endogeic lumbricids in arable soils. Soil Biol. Biochem. 1992, 24, 1595-1599. [CrossRef]

36. Singh, J.; Schädler, M.; Demetrio, W.; Brown, G.G.; Eisenhauer, N. Climate change effects on earthworms-A review. Soil Org. 2020, 91, 114-138.

37. Cooper, H.V.; Sjögersten, S.; Lark, R.M.; Girkin, N.T.; Vane, C.H.; Calonego, J.C.; Rosolem, C.; Mooney, S.J. To till or not to till in a temperate ecosystem? Implications for climate change mitigation. Environ. Res. Lett. 2021, 16, 054022. [CrossRef]

38. Rabot, E.; Cousin, I.; Hénault, C. A modeling approach of the relationship between nitrous oxide fluxes from soils and the water-filled pore space. Biodegradation 2014, 122, 395-408. [CrossRef]

39. Palm, C.; Blanco-Canqui, H.; DeClerck, F.; Gatere, L.; Grace, P. Conservation agriculture and ecosystem services: An overview. Agric. Ecosyst. Environ. 2014, 187, 87-105. [CrossRef]

40. Gregorich, E.; McLaughlin, N.; Lapen, D.; Ma, B.; Rochette, P. Soil Compaction, Both an Environmental and Agronomic Culprit: Increased Nitrous Oxide Emissions and Reduced Plant Nitrogen Uptake. Soil Sci. Soc. Am. J. 2014, 78, 1913-1923. [CrossRef] 